\title{
FAKTOR - FAKTOR LOKAL DAN GLOBAL DALAM IMPLEMENTASI MANAJEMEN PENDIDIKAN ISLAM
}

\author{
Helmiati \\ Madrasah Aliyah Negeri 1 Bungo \\ Email: helmiatiemi5@gmail.com
}

\begin{abstract}
Education is a very important element in the process of giving birth to a great noble generation. This achievement can only be obtained if the education management system implemented is categorized as good. In this case, it also includes the management of Islamic education. Islamic education management aims to establish beneficial cooperation between members of educational institutions in order to achieve the vision and mission of the institution. However, currently the implementation of Islamic education management is still experiencing significant obstacles. This is because the concepts of Islamic education management are not familiar with Islamic educatioal institutions. Included in the local and global nuances in the implementation process. This study aims to examine the implementation of Islamic education management in local and global contexts and to discuss local and global factors in the implementation of Islamic education management. This research is a case study using a qualitative approach. The results achieved from this research are: 1) as for local factors in the implementation of Islamic education management, namely: state ideology, community development, scientific development. 2) while the global factors in the implementation of Islamic education management are: Islamic education personnel management, Islamic education student management, Islamic education curriculum management and Islamic education infrastructure management.
\end{abstract}

Keywords: Local Factors, Global Factors, Implementation, Islamic Education Management.

\begin{abstract}
Abstrak
Pendidikan adalah elemen yang sangat penting dalam proses melahirkan generasi hebat serta berakhlak mulia. Pencapaian ini hanya akan bisa didapatkan jika sistem manajemen pendidikan yang dilakukan sudah terkategori baik. Dalam hal ini, juga termasuk manajemen pendidikan Islam. Manajemen pendidikan Islam bertujuan untuk membentuk kerjasama yang menguntungkan antara anggota lembaga pendidikan guna mencapai visi dan misi lembaga. Namun, saat ini implementasi manajemen pendidikan Islam masih mengalami kendala yang berarti. Hal ini disebabkan karena belum familiarnya konsep-konsep manajemen pendidikan Islam pada institusi-institusi pendidikan Islam. Termasuk dalam nuansa lokal dan global dalam proses Implementasinya. Penelitian ini bertujuan untuk mengkaji implementasi
\end{abstract}

Nur El-Islam, Volume 8, Nomor 1, April 2021 
manajemen pendidikan Islam pada konteks lokal dan global serta membahas faktorfaktor lokal dan global dalam implementasi manajemen pendidikan Islam. Penelitian ini merupakan studi kasus dengan menggunakan pendekatan kualitatif. Hasil yang dicapai dari penelitian ini adalah: 1) adapun factor-faktor lokal dalam implementasi manajemen pendidikan Islam yaitu: Ideologi negara, perkembangan masyarakat, perkembangan ilmu pengetahuan. 2) sedangkan faktor global dalam implementasi manajemen pendidikan Islam yaitu: Manajemen personalia pendidikan Islam, manajemen kesiswaan pendidikan Islam, manajemen kurikulum pendidikan Islam dan manajemen sarana prasarana pendidikan Islam.

Kata Kunci: Faktor Lokal, Faktor Global, Implementasi, Manajemen Pendidikan Islam.

\section{Pendahuluan}

\section{A. Latar Belakang Masalah}

Pendidikan adalah elemen penting dalam proses tumbuh besar dan kematangan seseorang yang dapat melahirkan generasi berguna serta berakhlak mulia. Untuk mencapai hasil tersebut, maka pendidikan mesti dikelola dengan manajemen pendidikan yang baik. Hal itu disebabkan karena maju berkembangnya sebuah lembaga pendidikan tergantung dari sistem manajemennya. Manajemen pendidikan yang baik akan mampu mengejar kesuksesan perkembangan anak manusia melalui pelayanan-pelayanan pendidikan yang memadai. ${ }^{1}$ Menurut Nanang Fattah, teori manajemen mempunyai peran (role) atau membantu menjelaskan prilaku organisasi yang berkaitan dengan motivasi, produktivitas, dan kepuasan (satisfaction). ${ }^{2}$ Dalam hal ini, juga termasuk dengan manajemen pendidikan Islam. Manajemen pendidikan Islam bertujuan untuk membentuk kerjasama yang menguntungkan antara anggota lembaga pendidikan tersebut dalam rangka pencapaian visi suatu lembaga. Manajemen pendidikan islam berkaitan erat dengan masalah pengelolaan lembaga pendidikan Islam.

${ }^{1}$ Mujami Qomar, Manajemen Pendidikan Islam: Strategi Baru Pengelolaan Pendidikan Islam, (Jakarta : Erlangga, 2007), hal 3

${ }^{2}$ Nanang Fattah, Landasan Manajemen Pendidikan, (Bandung: Rosdakarya, 2002), hal 11 
Implementasi Manajemen Pendidikan Islam, sampai saat ini masih mengalami kendala yang berarti. Hal ini disebabkan karena belum familiarnya konsep-konsep manajemen pendidikan islam pada institusi-institusi pendidikan Islam. Termasuk dalam nuansa lokal dan global dalam proses Implementasinya. Menurut Mujamil Qomar bahwa manajemen komponen-komponen dasar pendidikan islam terdiri atas: (1) Manajemen Personalia Pendidikan Islam, (2) Manajemen Kesiswaan Pendidikan Islam, (3) Manajemen Kurikulum Pendidikan Islam, (4) Manajemen Keuangan Pendidikan Islam, dan (5) Manajemen Sarana dan Prasarana Pendidikan Islam ${ }^{3}$.

Implementasi sistem pendidikan Islam diberbagai negara yang berpenduduk muslim mempunyai corak serta sistem yang berbeda. Di negara yang mayoritas penduduknya beragam Islam seperti Indonesia dan Malaysia berbeda nuansa implementasinya dengan negara yang relatif berimbang antara setiap pemeluknya, misalnya negara tersebut memiliki pluralitas agama, dominasi penguasa atau"political will" seperti Singapura dan Brunei Darussalam. ${ }^{4}$ Perbedaan tersebut dapat dilihat dari beberapa manajemen komponen-komponen pendidikan islam, seperti kurikulum, dimana untuk local (Indonesia) kurikulum yang digunakan dalam lembaga pendidikan Islam adalah kkurikulum yang sudah terintegrasi antara pendidikan Islam dengan pendidikan modern, namun untuk beberapa negara eropa dan afrika, kurikulum yang digunakan dalam manajemen pendidikan islam adalah kurikulum yang masih original tanpa integrasi kurikulum modern. Selain itu, terdapat perbedaan dalam proses pelaksanaan kurikulum pembelajaran antara local dengan global, seperti di Indonesia terkenal dengan 1001 metode pembelajaran, sementara kalau kita lihat pelaksanaan pembelajaran di mesir sebagai pusatnya pendidikan islam masih menggunakan metode holaqoh. Nah, inilah yang menarik

\section{5-177.}

${ }^{3}$ Mujamil Qomar, Manajemen Pendidikan Islam, (Jakarta: Erlangga, 2015), hal.

${ }^{4}$ Amrullah Ahmad, et.al., Dimensi Hukum Islam dalam Sistim Hukum Nasional (Cet. I; Jakarta: Gema Insani Press, 1996), h. xi. Lihat juga Amir Mu'allim dan Yusdani, Konfigurasi Pemikiran Hukum Islam (Cet. I; Yogyakarta: UI Press, 1999). 
perhatian penulis untuk mengkaji mengenai implementasi manajemen pendidikan islam pada konteks local dan global.

\section{A. Rumusan Masalah}

Berdasarkan latar belakang masalah yang telah diuraikan di atas, maka yang menjadi pertanyaan dalam makalah ini adalah:

1. Apa itu manajemen pendidikan Islam?

2. Bagaimana implementasi manajemen pendidikan islam dalam lingkup lokal?

3. Bagaimana implementasi manajemen pendidikan islam dalam lingkup global?

\section{B. Tujuan dan Manfaat Penulisan}

Adapun yang menjadi tujuan dan manfaat dari makalah ini adalah:

1. Memahami definisi manajemen pendidikan islam.

2. Menganalisis implementasi manajemen pendidikan islam dalam lingkup lokal.

3. Menganalisis implementasi manajemen pendidikan islam dalam lingkup global.

\section{PEMBAHASAN}

\section{A. Definisi Manajemen Pendidikan Islam}

Sebelum mengkaji mengenai Manajemen Pendidikan Islam kita terlebih dahulu mengetahui definisi dari manajemen. Kata "manajemen" saat ini sudah banyak sekali di kenal di Indonesia, baik di lingkungan swasta, perusahaan, maupun pendidikan. Berdasarkan kenyataan yang ada ini menunjukan bahwa manajemen telah diterima dan dibutuhkan kehadirannya di masyarakat. Semula manajemen yang berasal dari bahasa Inggris: Management dengan kata kerja to manage, diartikan secara umum sebagai "mengurusi". Selanjutnya banyak penulis yang telah berusaha untuk memberikan definisi atau batasan tentang pengertian manajemen.

Menurut Marry papker Follett, “Manajemen sebagai seni dalam menyelesaikan pekerjaan melalui orang lain”. Pengertian ini mengandung arti bawa para manajer' mencapai tujuan-tujuan 
organisasi melalui pengaturan orang-orang lain untuk melaksanakan berbagai tugas yang memungkinkan diperlukan, atau berarti dengan tidak melakukan tugas-tugas itu sendiri" ${ }^{5}$

Sedangkan menurut James A.F. Stoner mengemukakan bahwa manajemen adalah proses perencanaan, pengorganisasian, pengarahan dan pengawasan usaha-usaha para anggota organisasi dan penggunaan sumber daya organisasi lainnya agar mencapai tujuan organisasi yang telah di etapkan. ${ }^{6}$

Manajemen juga sering diartikan sebagai ilmu pengetahuan karena manajemen dipandang sebagai suatu bidang pengetahuan yang secara sistematik berusaha memahami mengapa dan bagaimana seseorang bekerjasama untuk mencapai tujuan dan membuat system kerjasama ini lebih bermanfaat bagi kemanusiaan. ${ }^{7}$

Dalam pendidikan Islam dikenal juga manajemen pendidikan Islam. Secara umum, manajemen pendidikan Islam memiliki banyak kesamaan dengan manajemen pendidikan secara umum, namun ada perbedaan dalam beberapa karakter. Diantara karakteristik yang membedakan teori manajemen dalam Islam dengan teori lain adalah fokus dan konsen teori Islam terhadap segala variabel yang berpengaruh (influence) terhadap aktivitas manajemen dalam dan di luar organisasi (perusahaan, negara), dan hubungan perilaku individu terhadap faktor-faktor yang berpengaruh. Teori Islam memberikan injeksi moral dalam manajemen, yakni mengatur bagaimana seharusnya individu berprilaku. Tidak ada manajemen dalam Islam kecuali ada nilai atau etika yang melingkupinya, sebagaimana tidak mungkin membangun masyarakat muslim tanpa didasari dengan akhlak.

Mujamil Qomar menyatakan bahwa “manajemen pendidikan Islam adalah suatu proses pengelolaan secara islami terhadap lembaga pendidikan islam dengan cara menyiasati sunber-sumber belajar dan hal-hal yang terkait untuk mencapai tujuan pendidikan islam secara

${ }^{5}$ Muwahid Shulhan,Manajemen Pendidikan Islam ,(Yogyakarta:Teras,2013), hal. 6

${ }^{6}$ Ibid.,hal.7

${ }^{7}$ Sulistyorini. Manajemen Pendidikan Islam,(Yogyakarya: Teras, 2009), hal. 8 
efektif dan efisien."8 Dari kesemua definisi manajemen pendidikan islam yang sudah dijelaskan di atas, maka dapat disimpulkan bahwa Manajemen pendidikan Islam adalah suatu proses penataan/ pengelolaan lembaga pendidikan Islam yang melibatkan sumber daya manusia muslim dan non manusia dalam menggerakannya untuk mencapai tujuan pendidikan Islam secara efektif dan efisien.

\section{B. Implementasi Manajemen Pendidikan Islam}

Pengertian Implementasi Menurut Para Ahli adalah bahwa Implementasi adalah suatu tindakan atau pelaksanaan dari sebuah rencana yang sudah disusun secara matang dan terperinci. Implementasi biasanya dilakukan setelah perencanaaan sudah dianggap fix. Secara sederhana implementasi bisa diartikan pelaksanaan atau penerapan. Majone dan Wildavsky mengemukakan implementasi sebagai evaluasi. ${ }^{9}$ Adapun Schubert mengemukakan bahwa "implementasi adalah sistem rekayasa.

Beberapa definisi implementasi di atas memperlihatkan bahwa kata implementasi bermuara pada aktivitas, adanya aksi, tindakan, atau mekanisme suatu sistem. Ungkapan mekanisme mengandung arti bahwa implementasi bukan sekadar aktivitas, tetapi suatu kegiatan yang terencana dan dilakukan secara sungguh-sungguh berdasarkan acuan norma tertentu untuk mencapai tujuan kegiatan. Lebih lanjut Mujammil mengatakan bahwa makna definitif ini memiliki implikasiimplikasi yang saling terkait dan membentuk satu kesatuan sistem dalam implementasi manajemen pendidikan Islam. Implikasiimplikasi tersebut antara lain yaitu: Pertama, Proses pengelolaan lembaga pendidikan Islam secara Islami. Aspek ini menghendaki adanya muatan-muatan nilai Islam dalam proses pengelolaan lembaga pendidikan Islam. Misalnya, penekanan pada penghargaan, maslahat, kualitas, kemajuan, dan pemberdayaan. Selanjutnya, upava pengelolaan itu diupayakan bersandar pada pesan-pesan Al-Qur'an

8 Sulistyorini, M. Faturrohman, Esensi Manajemen Pendidikan Islam,(Yogyakarta:Teras, 2014) hal.11

${ }^{9}$ Robbin dan Coulter, Manajemen (edisi kedelapan), , (Jakarta, PT Indeks 2007), hal 48 
dan hadis agar selalu dapat menjaga sifat Islami. Kedua, Terhadap lembaga pendidikan Islam. Hal ini menunjukkan objek dari manajemen ini yang secara khusus diarahkan untuk menangani lembaga pendidikan Islam dengan segala keunikannya. Maka, manajemen ini bisa memaparkan cara-cara pengelolaan pesantren, madrasah, perguruan tinggi Islam, dan sebagainya.

Ketiga, Proses pengelolaan lembaga pendidikan Islam secara Islami menghendaki adanya sifat inklusif dan eksklusif. Frase secara islami menunjukkan sikap inklusif, yang berarti kaidah-kaidah manajerial yang dirumuskan dalam buku ini bisa dipakai untuk pengelolaan pendidikan selain pendidikan Islam selama ada kesesuaian sifat dan misinya. Dan sebaliknya, kaidah-kaidah manajemen pendidikan secara umum bisa juga dipakai dalam mengelola pendidikan Islam selama sesuai dengan nilai-nilai Islam, realita, dan kultur yang dihadapi lembaga pendidikan Islam. Sementara itu, frase lembaga pendidikan Islam menunjukkan keadaan eksklusif karena menjadi objek langsung dari kajian ini, hanya terfokus pada lembaga pendidikan Islam”. Sedangkan, lembaga pendidikan lainnya telah dibahas secara detail dalam buku-buku manajemen pendidikan. Keempat, Dengan cara menyiasati. Frase ini mengandung strategi yang menjadi salah satu pembeda antara administrasi dengan manajemen. Manajemen penuh siasat atau strategi yang diarahkan untuk mencapai suatu tujuan. Demikian pula dengan manajemen pendidikan Islam yang senantiasa diwujudkan melalui strategi tertentu. Adakalanya strategi tersebut sesuai dengan strategi dalam mengelola lembaga pendidikan umum, tetapi bisa jadi berbeda sama sekali lantaran adanya situasi khusus yang dihadapi lembaga pendidikan Islam. Kelima, Sumber-sumber belajar dan halhal lain yang terkait. Sumber belaiar di sini memiliki cakupan yang cukup luas, yaitu: (1) Manusia, yang meliputi guru/ ustadz/ dosen, siswa/ santri/ mahasiswa, para pegawai, dan para pengurus yayasan; (2) Bahan, yang meliputi perpustakaan, buku palajaran, dan sebagainya; (3) Lingkungan, merupakan segala hal yang mengarah 
pada masyarakat; (4) Alat dan peralatan, seperti laboratorium; dan (5) Aktivitas. ${ }^{10}$

\section{Faktor-faktor Lokal dalam Implementasi Manajemen Pendidikan Islam}

\section{Faktor Ideologi Negara}

Antara pendidikan Islam dan pendidikan nasional Indonesia tidak dapat dipisahkan satu dengan yang lain. Hal ini dapat ditelusuri dari dua segi: Pertama, dari konsep penyusunan sistem pendidikan nasional Indonesia itu sendiri. Kedua, dari hakikat pendidikan Islam dalam kehidupan beragama kaum muslimin di Indonesia. Penyusunan suatu sistem pendidikan nasional harus mementingkan masalahmasalah eksistensi umat manusia pada umumnya dan eksistensi bangsa Indonesia pada khususnya baik dalam hubungannya dengan masa lampau, masa kini dan kemungkinan-kemungkinan perkembangan masa depan.

Eksistensi bangsa Indonesia terwujud dengan proklamasi kemerdekaan pada tanggal 17 Agustus 1945, dimana bangsa Indonesia sebagai negara yang merdeka, bersatu dan berdaulat penuh. Bangsa Indonesia telah bertekad bulat untuk membangun dan mengembangkan bangsa dengan Pancasila sebagai landasan Ideologi dan Undang-Undang Dasar 1945 sebagai landasan konstitusionalnya. Sejak dari awal Indonesia merdeka, pemerintah telah menempatkan agama sebagai fondasi dalam membangun bangsa dan negara. Hal ini dapat kita baca dalam Undang-Undang Dasar 1945. Dalam pembukaan UUD 1945 alinea ketiga dinyatakan bahwa kemerdekaan Indonesia adalah semata-mata atas berkat rahmat Tuhan Yang Maha Kuasa, dan pada alinea keempat dinyatakan bahwa Pancasila menjadi dasar negara. Namun apabila dilihat kembali perjalanan sejarah para pemimpin nomor satu di negeri ini dalam menafsirkan ideologi

\footnotetext{
${ }^{10}$ Mujammil Qomar, Manajemen Pendidikan Islam,(Jakarta: Erlangga, 2007) hal 36
} 
Pancasila dan mengimplementasikannya terhadap pendidikan Islam, dapat di bagi menjadi tiga orde ( masa ) yaitu : ${ }^{11}$

\section{a. Orde Lama}

Pancasila sebagai ideologi negara dianggap telah mewakili citacita semua agama dan golongan, termasuk umat Islam. Bahkan Presiden Soekarno pernah mengatakan bahwa semua agama itu sama, karena semua agama bertujuan untuk mencapai kebaikan hidup manusia. Presiden Soekarno dengan demokrasi terpimpinnya berulangkali berhasil "menjinakkan" dan mementahkan perjuangan politik Islam yang kemudian berimbas ke pendidikan Islam. Penjinakan itu berupa memarginalisasi partai politik Islam dan aspirasi umat Islam dengan alasan menjaga persatuan dan kesatuan bangsa Indonesia. Contoh kongkretnya adalah menghapus tujuh kata dalam "Piagam Jakarta" dalam UUD 45 “ Dengan Kepercayaan Terhadap Allah Yang Maha Kuasa”.

\section{b. Orde Baru}

Pada awal-awal pemerintahannya Presiden Soeharto mengadakan konsolidasi yang diiringi dengan kebijakan yang represif terhadap Islam. Karena Soeharto melihat Islam sebagai ancaman. Maka antara Pemerintah dan islam selalu ada hubungan antagonis yaitu hubungan yang saling curiga dan saling tidak percaya. Pada pertengahan pemerintahannya Presiden Suharto mencetuskan idiologi Pancasila sebagai asas tunggal untuk partai politik dan keagamaan. Hubungan antara pemerintah dan umat Islampun makin menegang. Peristiwa "Tanjung Priok“ 12 September 1984, yang memakan ratusan korban adalah salah satu contohnya.

\section{c. Orde Reformasi}

Dengan bergulirnya masa reformasi yang ditandai dengan demokratisasi sebagai salah satunya, membawa angin segar bagi pendidikan Islam atau lembaga pendidikan Islam. Keluarnya Peraturan Pemerintah (PP) nomor 55 tahun 2007 tentang Pendidikan Agama dan Pendidikan Keagamaan, diharapkan dapat membawa perubahan pada sisi managerial dan proses Pendidikan Islam.

${ }^{11}$ Deliar Noer, Pembangunan di Indonesia, (Jakarta: Mutiara, 2004), hal. 45 
Peraturan Pemerintah (PP) tersebut secara eksplisit mengatur bagaimana seharusnya Pendidikan Keagamaan Islam dan Keagamaan diselenggarakan. Hanya saja realitas yang ada sampai saat ini masih terkesan, secara kelembagaan Pendidikan Islam menempati posisi kedua setelah Pendidikan Nasional. Sebuah lembaga yang menawarkan Pendidikan Islam kurang banyak diminati jika dibanding dengan lembaga lain yang dianggap lebih menjanjikan. Dan sampai saat inipun, posisi Pendidikan Islam belum beranjak dari sekedar sebuah subsistem dari sistem Pendidikan Nasional.

\section{Faktor Perkembangan Masyarakat}

Perkembangan masyarakat dunia pada umumnya dan Indonesia pada khususnya mau tidak mau akan menuju kepada masyarakat informasi (informatical society) sebagai kelanjutan atau perkembangan dari masyarakat industri atau modern. Jika masyarakat modern memiliki ciri-ciri rasional, berorientasi ke depan, bersikap terbuka, menghargai waktu, kreatif, mandiri dan inovatif, maka pada masyarakat informasi ciri-ciri tersebut belum cukup. Pada masyarakat informasi, manusia selain harus memiliki ciri-ciri masyarakat modern pada umumnya, juga harus memiliki ciri-ciri lain, yaitu menguasai dan mampu mendayagunakan arus informasi, mampu bersaing, terus menerus belajar (serba ingin tahu), mampu menjelaskan, imajinatif, mampu mengubah tantangan menjadi peluang, dan menguasai kemampuan menggunakan berbagai metode dalam memecahkan berbagai masalah yang dihadapi.

Pada masyarakat informasi peranan media elektronika sangat memegang peranan penting dan bahkan menentukan corak kehidupan. Penggunaan teknologi elektronika seperti komputer, faksimile, internet dan lain-lain telah mengubah lingkungan informasi dari lingkungan yang bercorak lokal dan nasional, kepada lingkungan yang bersifat internasional, mendunia dan global. Pada era informasi, lewat komunikasi satelit dan komputer orang memasuki lingkungan informasi dunia. Peran media elektronik yang demikian besar akan menggeser agen-agen sosialisasi yang berlangsung secara tradisional seperti yang dilakukan orang tua, guru, pemerintah dan sebagainya. 
Komputer dapat menjadi teman bermain, orang tua yang akrab, guru yang memberi nasehat, juga sewaktu-waktu dapat memberikan jawaban segera terhadap pertanyaan-pertanyaan eksistensial dan mendasar.

Kemajuan dalam bidang informasi tersebut pada akhirnya akan berpengaruh pada kejiwaan dan kepribadian masyarakat. Pada era informasi yang sanggup bertahan hanyalah mereka yang berorientasi ke depan, yang mampu mengubah pengetahuan menjadi kebijakan dan ciri-ciri lain sebagaimana dimiliki oleh masyarakat modern. Itulah gambaran masa depan yang akan terjadi, dan umat manusia mau tidak mau harus menghadapinya. Masa depan yang demikian itu selanjutnya akan mempengaruhi dunia pendidikan, baik dari kelembagaan, materi pendidikan, guru, metode, sarana dan prasarana dan lain sebagainya. Hal ini pada gilirannya menjadi tantangan yang harus dijawab oleh dunia pendidikan khususnya pendidikan Islam. Hal ini perlu dilakukan jika dunia pendidikan Islam ingin tetap bertahan secara fungsional dalam memandu perjalanan umat manusia.

Berkenaan dengan hal tersebut perlu dilakukan upaya-upaya strategis dalam implementasi manajemen pendidikan Islam, antara lain:

a. Tujuan pendidikan di masa sekarang tidak cukup hanya dengan memberikan bekal pengetahuan, keterampilan, keimanan dan ketakwaan saja, tetapi juga harus diarahkan pada upaya melahirkan manusia yang kreatif, inovatif, mandiri, dan produktif, mengingat dunia yang akan datang adalah dunia yang kompetitif.

b. Guru di masa mendatang adalah guru yang selain memiliki informasi, berakhlak baik dan mampu menyampaikannya secara metodologis, juga harus mampu mendayagunakan berbagai sumber informasi yang tersebar di masyarakat ke dalam kegiatan belajar. Dengan demikian pembelajaran harus lebih memusat pada siswa yang pada gilirannya dapat menimbulkan masyarakat belajar.

c. Bahan pelajaran umum dan agama perlu diintegrasikan dan diberikan kepada siswa sebagai yang memungkinkan ia dapat memiliki pribadi yang utuh, yaitu pribadi disamping berilmu 
pengetahuan juga harus berakhlak mulia. Hal ini penting karena kehidupan masa mendatang banyak dihadapkan pada tantangan yang bersifat moral. Untuk itu, perlu dikembangkan pengamalan akhlak di sekolah-sekolah. ${ }^{12}$

\section{Faktor Perkembangan Ilmu Pengetahuan}

Kemajuan teknologi dalam tiga dasawarsa ini telah menampakkan pengaruhnya pada setiap dan semua kehidupan individu, masyarakat dan negara. Dapat dikatakan bahwa tidak ada orang yang dapat menghindar dari pengaruh perkembangan ilmu pengetahuan dan teknologi (IPTEK), IPTEK bukan saja dirasakan individu, akan tetapi dirasakan pula oleh masyarakat, bangsa dan negara. Kehadiran IPTEK di negara-negara maju, sudah lama dirasakan pengaruhnya, karena pada negara-negara tersebutlah kemajuan itu mula-mula dicapai. Sebaliknya bagi negara-negara berkembang, pengaruh tersebut baru mulai dirasakan antara lain seperti dalam bidang informasi, buku-buku, media TV, radio, video, internet dan lain sebagainya.

Sekarang yang menjadi persoalan sekaligus pertanyaan bagi kita tentunya adalah bagaimana dengan eksistensi pendidikan Islam dalam menghadapi arus perkembangan IPTEK yang sangat pesat tersebut. Bagaimanapun tampaknya pendidikan Islam (terutama lembaganya) dituntut untuk mampu mengadaptasikan dirinya dengan kondisi yang ada. Disamping dapat mengadaptasi dirinya, pendidikan Islam juga dituntut untuk menguasai IPTEK, dan kalau perlu merebutnya. Kenyataan untuk merebut teknologi dan ilmu pengetahuan tersebut adalah sangat penting, sebab sekarang pembangunan nasional diarahkan dengan orientasi pada teknologi industri, dalam hal ini tak terkecuali dalam bidang pendidikan.

Sementara itu pendidikan Islam yang tugas pokoknya menelaah dan menganalisis serta mengembangkan pemikiran, informasi dan

${ }^{12}$ Abuddin Nata, Paradigma Pendidikan Islam: Kapita Selekta Pendidikan Islam, (Jakarta: Gramedia Widiasarana, 2011). 
fakta-fakta kependidikan yang sama sebangun dengan nilai-nilai ajaran Islam dituntut harus mampu mengetengahkan perencanaan program-program dan aktivitas-aktivitas operasional kependidikan, terutama yang berkaitan dengan pengembangan dan pemanfaatan IPTEK sebagaimana digambarkan diatas. Strategi Implementasi Manajemen Pendidikan Islam dalam menghadapi tantangan lokal berkat kemajuan IPTEK itu mencakup ruang lingkup:

a. Motivasi kreatifitas anak didik ke arah pengembangan IPTEK itu sendiri, dimana nilai-nilai Islam menjadi sumber acuannya.

b. Mendidik keterampilan, memanfaatkan produk IPTEK bagi kesejahteraan hidup umat manusia pada umumnya dan umat Islam pada khususnya.

c. Menciptakan jalinan yang kuat antara ajaran agama dan IPTEK, dan hubungan yang akrab dengan para ilmuwan yang memegang otoritas IPTEK dalam bidang masing-masing.

d. Menanamkan sikap dan wawasan yang luas terhadap kehidupan masa depan umat manusia melalui kemampuan menginterpretasikan ajaran agama dari sumber-sumbernya yang murni dan kontekstual dengan masa depan kehidupan manusia. ${ }^{13}$

Jadi implemetasi manajemen pendidikan Islam diarahkan, agar pendidikan Islam tidak hanyut terbawa arus modernisasi dan kemajuan IPTEK. Strategi tersebut merupakan sebagian solusi bagi pendidikan Islam untuk bisa lebih banyak berbuat. Kendatipun demikian, pendidikan Islam tentu saja tidak boleh lepas dari Idealitas Al-Qur'an dan As-Sunnah yang berorientasikan kepada hubungan manusia dengan Allah SWT. (Hablumminallah), hubungan manusia dengan sesamanya (Hablumminannas) dan dengan alam sekitarnya.

Dari ketiga orientasi tersebut, tampaknya hubungan dengan alam sekitar menjadi dasar pengembangan IPTEK, sedang Hablumminallah menjadi dasar pengembangan sikap dedikasi dan

${ }^{13}$ Altaf Gauhar, Tantangan dalam Pendidikan Islam, (Jakarta: Raja Grafindo Persada, 2006), hal. 37 
moralitas yang menjiwai pengembangan IPTEK, sedang Hablumminannas menjadi dasar pengembangan hidup bermasyarakat yang berpolakan atas kesinambungan, keserasian, dan keselarasan dengan nilai-nilai moralitas yang berfungsi menentramkan jiwa manusia, sehingga terciptalah kedamaian.

Dengan demikian apa dan bagaimanapun produk-produk hasil pengembangan ilmu pengetahuan dan teknologi akan senantiasa bernilai positif, serta mendatangkan kemanfaatan bagi kehidupan manusia.

\section{Faktor-faktor Global dalam Implementasi Manajemen Pendidikan Islam}

Dalam pembahasan faktor global dalam implementasi manajemen pendidikan islam, maka penulis berakar dari lima manajemen komponen-komponen dasar pendidikan islam seperti yang sudah dipaparkan pada bagian pendahuluan di atas, yaitu:

\section{Manajemen Personalia Pendidikan Islam}

Manajemen personalia/ SDM pendidikan sangatlah penting fungsinya bagi keberhasilan lembaga pendidikan. Manajemen personalia adalah aktivitas yang harus dilakukan mulai dari tenaga pendidik dan kependidikan itu masuk kedalam organisasi pendidikan sampai akhirnya berhenti melalui proses perencanaan, perekrutan, seleksi, penempatan, pemberian kompensasi, penghargaan, pendidikan dan pelatihan tenaga pendidik dan kependidikan ${ }^{14}$. SDM merupakan subtansi penting dalam organisasi. Oleh Karena itu, SDM harus dikelola dengan baik untuk meningkatkan keefektifan dan efisiensi organisasi pendidikan.

Dalam Islam pengelolaan sumber daya manusia mengacu pada apa yang dicontohkan oleh Nabi Muhammad SAW yang didasarkan pada konsep Islam mengenai manusia itu sendiri. Konsep Pertama: Manusia diciptakan untuk beribadah kepada Tuhan. Oleh karena itu segala kegiatan manusia harus merupakan bentuk ibadah, ibadah

${ }^{14}$ Imam Gunawan dan Djum Djum Noor Benty, Manajemen Pendidikan: Suatu Pengantar Praktik, (Bandung: Alfabeta CV, 2017), hal. 129 
dalam arti luas, tidak hanya ibadah yang bersifat ritual. Setiap kegiatan manusia bisa bernilai ibadah jika diniatkan untuk mencari keridhoan Tuhan. Bermasyarakat yang baik adalah ibadah, bekerja dengan giat merupakan ibadah, bahkan tidur pun bisa bernilai ibadah. Konsep kedua: Manusia adalah khalifatullah fil ardhli (wakil Allah di bumi), yang bertugas memakmurkan bumi. Konsekuensi dari kedua konsep ini adalah segala kegiatan manusia akan dinilai dan dipertanggungjawabkan kelak di akhirat. Dengan konsep tersebut Islam memandang bahwa masalah manusia bukan masalah yang sepele.

Islam mengusahakan sumber daya manusia untuk ikut memakmurkan bumi dalam lingkup pengabdian kepada Tuhan dengan memanfaatkan seoptimal mungkin potensi yang telah dianugerahkan oleh Tuhan. Dalam hal recruitment \& selection, Rasulullah sangat mementingkan profesionalisme. Beliau bersabda, “Jika suatu urusan diserahkan kepada yang bukan ahlinya, maka tunggulah saat (kehancuran)-nya." (HR Bukhari dan Ahmad). Rasulullah juga bersabda, "Siapa yang mengangkat seseorang sebagai pegawai dari suatu kaum, padahal pada kaum itu terdapat seseorang yang diridhai Allah (cakap, soleh dan beriman) maka ia telah berkhianat kepada Allah, Rasul-Nya dan orang-orang beriman. (HR al-Hakim). Rasulullah sangat memperhatikan masalah remunerasi. Dalam hadis riwayat Abdur-Razzaq dari Abu Hurairah dan Abu Sa'id al-Khudri, Nabi s.a.w.bersabda: "Barang siapa mempekerjakan pekerja, beritahukanlah upahnya." Sedangkan dalam Hadis Riwayat Ibn Majah dari Ibnu Umar, bahwa Nabi bersabda: "Berikanlah upah pekerja sebelum keringatnya kering."

Hasan Langgulung mengemukakan beberapa pemikirannya tentang strategi pendidikan Islam dalam meningkatkan kualitas sumber daya manusia diantaranya dapat ditempuh melalui dari dua model, yaitu strategi pendidikan yang bersifat makro dan strategi pendidikan yang bersifat mikro. Strategi yang bersifat makro terdiri dari tiga komponen utama, yaitu pertama, tujuan pendidikan Islam yang mencakup pembentukan insan shaleh dan masyarakat shaleh. Kedua, dasar-dasar pokok pendidikan Islam yang menjadi landasan 
kurikulum terdiri dari 8 aspek; keutuhan, keterpaduan, kesinambungan, keaslian, bersifat ilmiah, bersifat praktikal, kesetiakawanan, dan keterbukaan. Ketiga, prioritas dalam tindakan yang meliputi penyerapan semua anak-anak yang mencapai usia sekolah, kepelbagaian jalur perkembangan, meninjau kembali materi dan metode pendidikan, pengukuhan pendidikan agama, administrasi dan perencanaan, dan kerja sama regional dan antar Negara di dalam dunia Islam.

Sedangkan strategi yang bersifat mikro hanya terdiri dari satu komponen saja, yaitu tazkiyah al-nafs (pembersihan jiwa). Tazkiyah itu bertujuan membentuk tingkah laku baru yang dapat mengimbangkan roh, akal, dan badan seseorang Dalam hubungannya dengan organizational management, Rasulullah adalah manager yang piawai dalam mendelegasikan suatu tugas kepada para sahabatnya. Kemampuan pendelegasian yang baik ini dikarenakan beliau sangat mengenal karakter, potensi dan (minat) masing-masing sahabatnya. Ada yang menarik dalam sejarah Islam, Umar bin Khatab adalah seorang yang tinggi besar, kuat serta pandai berperang. Akan tetapi Umar tak pernah diangkat menjadi panglima perang. Justru Usamah, pemuda 16 tahun, pernah ditugaskan menjadi seorang panglima perang. Itu karena Rasulullah paham, bahwa selain memiliki kompetensi dalam berperang, Umar memiliki kompetensi sebagai seorang pemimpin (khalifah). Dan ia disiapkan untuk itu.

Rasulullah juga telah mencontohkan implementasi Participative Management. Beliau kerap melibatkan para sahabatnya dalam pengambilan keputusan. Contoh yang monumental tentang manajemen partisipatif ini bisa dilihat dari keberhasilan Rasul dan sahabat dalam perang Khandaq. Di samping itu, Rasulullah juga sangat piawai dalam memberikan motivasi kepada sahabatnya secara tepat sesuai keadaan sahabatnya. Beliau tidak hanya memotivasi untuk masalah akhirat saja, Beliau juga memotivasi para sahabatnya untuk selalu optimal di semua posisi dan peran kehidupan masingmasing. Yang menarik adalah Rasulullah memberikan perhatian yang istimewa kepada semua sahabatnya, sehingga diriwayatkan bahwa setiap sahabat merasa bahwa dia adalah orang yang paling 
diperhatikan dan dicintai Rasul-Nya.Inilah salah satu bentuk immaterial compensation yang dicontohkan oleh Rasulullah. Pada praktiknya, Rasulullah tidak hanya sebagai seorang manager, beliau adalah seorang leader. Dan lebih dari itu, beliau tidak hanya menjadi seorang leader, tetapi leader yang mampu mencetak leader-leader unggul.Hal ini bisa dilihat dari jejak khulafaur rasyidin dan semua sahabatnya.

Dari ketiga nilai diatas menghasilkan Etos kerja yang berimplikasi kepada seorang manajer pendidikan Islam sebagai berikut :

a. Tidak boleh bekerja dengan sembrono, seenaknya dan acuh tak acuh. Sebab hal ini bertentangan dengan Al Quran Surat Al Kahfi , ayat 110 .

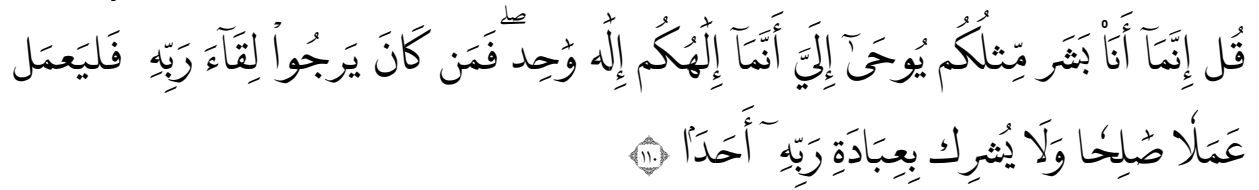

Artinya: Sesungguhnya aku ini manusia biasa seperti kamu, yang diwahyukan kepadaku: "Bahwa sesungguhnya Tuhan kamu itu adalah Tuhan yang Esa". Barangsiapa mengharap perjumpaan dengan Tuhannya, maka hendaklah ia mengerjakan amal yang saleh dan janganlah ia mempersekutukan seorangpun dalam beribadat kepada Tuhannya"

b. Setiap orang dinilai dari hasil kerjanya (QS al Najm, 39)

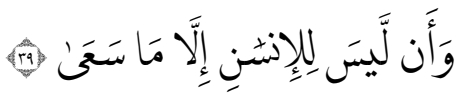

Artinya: dan bahwasanya seorang manusia tiada memperoleh selain apa yang telah diusahakannya

c. Bekerja secara optimal dan komitmen terhadap proses dan hasil kerja yang bermutu (QS. An Naml; 90)

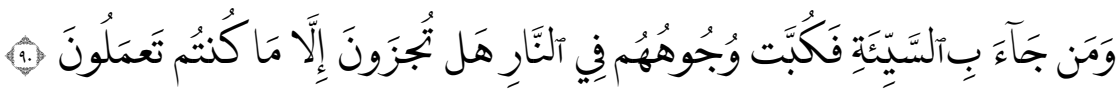


Artinya: Dan barang siapa yang membawa kejahatan, maka disungkurkanlah muka mereka ke dalam neraka. Tiadalah kamu dibalasi, melainkan (setimpal) dengan apa yang dahulu kamu kerjakan

d. Bekerja secara efisien dan efektif atau mempunyai daya guna yang setinggi-tingginya (QS Sajadah: 7)

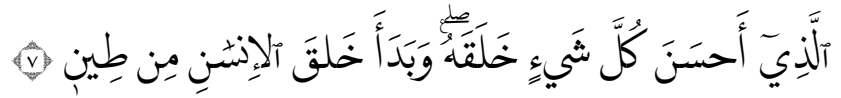

Artinya: Yang membuat segala sesuatu yang Dia ciptakan sebaik-baiknya dan Yang memulai penciptaan manusia dari tanah

e. Mengerjakan sesuatu dengan sungguh-sungguh dan teliti dan tidak separuh hati atau setengah-setengah (QS An Naml: 88)

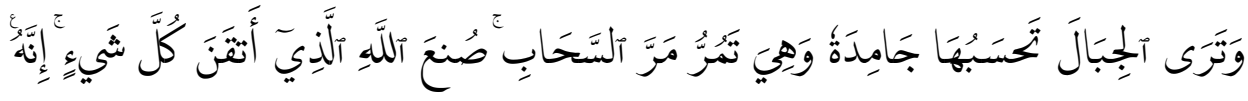

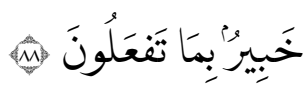

Artinya: Dan kamu lihat gunung-gunung itu, kamu sangka dia tetap di tempatnya, padahal ia berjalan sebagai jalannya awan. (Begitulah) perbuatan Allah yang membuat dengan kokoh tiap-tiap sesuatu; sesungguhnya Allah Maha Mengetahui apa yang kamu kerjakan

f. Memiliki dinamika yang tinggi, komitmen terhadap masa depan, memiliki kepekaan terhadap perkembangan masyarakat serta IPTEK dan bersikap Istiqamah (QS al Syarh: 7-8, ad Dhuha: 4, al alaq: $1-3$, as Syura: 15 )

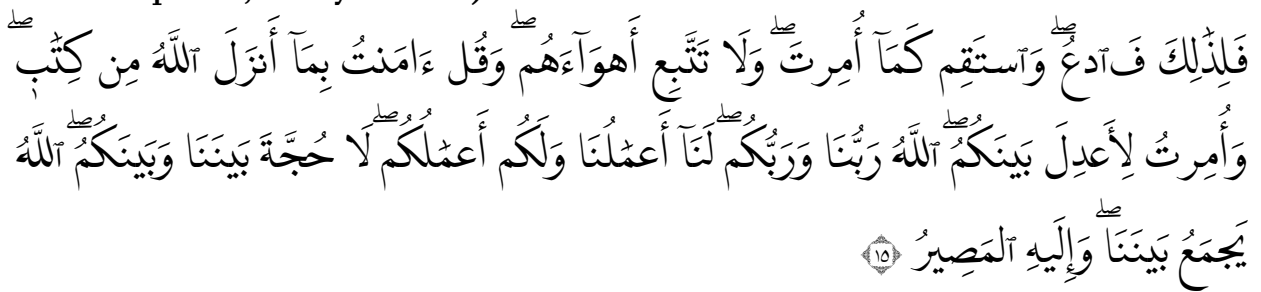

Artinya: Maka karena itu serulah (mereka kepada agama ini) dan tetaplah sebagai mana diperintahkan kepadamu dan janganlah mengikuti hawa 
nafsu mereka dan katakanlah: "Aku beriman kepada semua Kitab yang diturunkan Allah dan aku diperintahkan supaya berlaku adil diantara kamu. Allah-lah Tuhan kami dan Tuhan kamu. Bagi kami amal-amal kami dan bagi kamu amal-amal kamu. Tidak ada pertengkaran antara kami dan kamu, Allah mengumpulkan antara kita dan kepada-Nya-lah kembali (kita)"

Di kancah global, praktik manajemen SDM seperti yang dilakukan Rasulullah terdahulu, sudah dilakukan dengan tanpa disadarinya. Seperti kita lihat pada bagian recruitment \& selection, negara-negara dengan pencapaian pendidikan yang berhasil sangat peka dengan hal ini. Seperti contoh, Finlandia, Singapura dan Jepang yang menjadi negara percontohan untuk pendidikan dua decade terakhir. Finlandia sangat ketat dalam hal recruitment, seperti yang penulis kutip dari buku yang berjudul "Teach like Finland" bahwa untuk menjadi tenaga pengajar di Finlandia harus minimal S2 dan merupakan 10 lulusan terbaik setiap universitas dengan ijazah guru. Sementara di Jepang, yang lebih mencengangkan adalah syarat menjadi pengajar Anak Usia Dini (AUD) adalah Profesor.

Makanya tak ayal bahwa ujian (tes) menjadi guru di Finlandia, Singapura dan Jepang lebih sulit dibandingkan ujian menjadi dokter dan pengacara. Sehingga di Finlandia profesi guru merupakan profesi yang sangat bergengsi dan terhormat ${ }^{15}$, sejajar dengan dokter dan pengacara. Begitu juga Singapura yang merupakan negara peraih ranking terbaik untuk PISA tahun 2016 yang lalu. Dalam hal manajemen personalia, Singapura tidak jauh berbeda dengan Finlandia.

Di Indonesia bagaimana? Sangat menyedihkan melihat Indonesia saat ini, negara dengan mayoritas muslim yang idealnya mengimplementasikan setiap tata kelola organisasi pendidikan sesuai Al-quran dan Al-Hadits di atas, malah tidak diikuti. Ada rasa malu juga sebenarx jika kita melihat fakta yang terjadi sekarang, di Indonesia penduduknya mayoritas muslim, tapi dari banyaknya

\footnotetext{
${ }^{15}$ Teach Like Finland,
} 
muslim tersebuit, belum semunya yang Islam. Salah satunya indikasinya dapat kita liihat dari hal recruitment. Indonesia masih diwarnai dengan "Korupsi Kolusi dan Nepotisme/ KKN" dalam perekrutan tenaga pendidik.

Prinsip “The Right Man on The Right Place" bukanlah jadi pertimbangan lagi, padahal Rasulullah jelas-jelas mengatakan bahwa barang siapa yang menempatklan seseorang tidak pada tempat yang tepat, maka tunggulah kehancuran (HR Bukhari dan Ahmad). Rasulullah juga bersabda, "Siapa yang mengangkat seseorang sebagai pegawai dari suatu kaum, padahal pada kaum itu terdapat seseorang yang diridhai Allah (cakap, soleh dan beriman) maka ia telah berkhianat kepada Allah, Rasul-Nya dan orang-orang beriman. (HR alHakim).

Menoleh kepada negara kecil namun prestasi pendidikannya saat ini sudah dikenal dunia seperti Finlandia, Singapura dan Jepang, dapat disimpulkan bahwa yang menyebabkan namanya dikenal dunia adalah karena kualitas pendidikannya yang bagus, dan peneyebab bagusnya pendidikan mereka adalah manajemen SDM yang bagus pula, salah satunya adalah kualitas pendidik yang memang teruji. Guru di Finlandia, Singapura dan Jepang terkenal dengan watak yang penyabar, memiliki jiwa toleransi dan guru memiliki komitmen untuk keberhasilan anak didiknya.

Jaminan terhadap kualitas tenaga pengajar juga terlihat di India yang saat ini pendidikannya juga mulai membaik bahwa keunggulan dan prestise seorang akademisi tidak diukur dengan indikator material, namun mengarah pada kultur akademis yang mencipta, dengan seberapa sering keilmuan dan pemikirannya yang dicurahkan dalam bentuk karya tulis masuk dalam jurnal internasional dan seberapa tinggi frekuensi mengajar di universitas lain terutama di kampus-kampus di luar negeri dan masih banyak lagi hal yang menjadi indikator bagi seorang profesor yang berkualitas yang masih bernuansa akademik di India, termasuk di Jamia Millia Islamia sebagai salah satu perguruan tinggi islam India yang paling terkenal.

Mutu jauh lebih penting bagi India.

Inilah yang jarang dilihat di Indonesia. Belum semua guru mengajar 
untuk meningkatkan kualitas dirinya, mengajar tidak dari hati, sehingga profesi guru di Indonesia saat ini masih sebatas profesi yang menjadi alternatif terakhir jika tidak mendapatkan pekerjaan yang lebih tinggi kelasnya.

\section{Manajemen kesiswaan pendidikan islam}

Manajemen peserta didik merupakan salah satu substansi manajemen pendidikan dan bersentuhan langsung dengan peserta didik. Memiliki peran yang strategis dalam mengembangkan potensipotensi peserta didik yang berbeda-beda. Peserta didik merupakan sentral layanan dari manajemen sekolah. Semua kegiatan yang ada di sekolah, baik yang berkenaan dengan peserta didik secara langsung ataupun tidak langsung diarahkan agar peserta didik mendapatkan layanan pendidikan yang andal. Manajemen peserta didik memiliki cakupan yang luas, yakni membantu proses pertumbuhan dan perkembangan peserta didik melalui proses pendidikan di sekolah ${ }^{16}$.

Disini, terdapat fakta yang menarik bagaimana implementasi manajemen kesiswaan/ peserta didik dilakukan pada kancah global. Kembali kita ke Finlandia, Singapura dan Jepang, bahwa salah satu hal mendasar yang membedakan bentuk implementasi manajemen kesiswaannya dengan kita (Indonesia) adalah bahwa di tiga negara tersebut, anak pintar dengan anak tidak pintar, tidak dibedakan sama sekali. Tidak ada yang namanya kelas unggul dan sekolah unggul. Semua anak sama, tidak ada kelas anak pintar dan kelas anak tidak pintar. Ketiga negara tersebut sangat tidak menyukai istilah kelas unggul, kelas biasa serta sekolah unggul dan sekolah biasa. Semua kelas dan sekolah di tiga negara tersebut sama-sama unggul.

Bagaimana dengan Indonesia? Jangkankan kita mengkaji kelas unggul dan kelas tidak unggul, yang merupakan turunan dari suatu sistem besar yaitu pendidikan, untuk jenis pendidikannya saja Indonesia sudah membagi dua model pendidikan atau yang diistilahkan dengan dualisme pendidikan. Dualisme pendidikan tersebut adalah model pendidikan islam dan model pendidikan

${ }^{16}$ Gunawan dan Benty, Manajemen Pendidikan, 2017: 128 
nasional. Di satu pihak, ada pendidikan yang hanya memperdalam ilmu pengetahuan modern yang kering dari nilai-nilai keagamaan, dan dipihak lain ada pendidikan yang hanya memperdalam masalah agama yang terpisahkan dari perkembangan ilmu pengetahuan. Dilihat dari kacamata Islam, ini jelas sangat jauh berbeda dengan konsep Islam tentang ilmu pengetahuan itu sendiri, karena dalam Islam ilmu dipandang secara utuh dan universal dan tidak ada istilah pemisahan atau dualisme/ dikotomi pendidikan. Sehingga hal inilah yang medorong Naquib Al-Attas dan Ismail Raji Al-Faruqi untuk mendengungkan konsep "Islamisasi ilmu pengetahuan"17.

Pendidikan Islam di Indonesia seperti tersisihkan dan serasa di nomor duakan. Hal ini terbukti dengan perlakuan dan perhatian pemerintah kepada sekolah-sekolah umum yang begitu istimewa dibanding perhatian dan perlakuan kepada madrasah-madrasah yang ada di Indonesia. Memang terasa janggal, dalam suatu komunitas masyarakat muslim, pendidikan Islam tidak diberi kesempatan yang sama untuk bersaing dalam membangun bangsa yang besar ini. Perhatian pemerintah yang dicurahkan kepada pendidikan Islam ini kecil porsinya, padahal masyarakat Indonesia sendiri selalu diharapkan agar tetap berada dalam lingkaran masyarakat sosialisreligius. Bahkan tidaklah salah jika dikatakan bahwa, pendidikan Islam di Indonesia justru menempati 'kelas dua' di dalam masyarakat yang mayoritas muslim.

\section{Manajemen kurikulum pendidikan Islam}

Oemar Hamalik mendefinisikan kurikulum sebagai program pendidikan yang disediakan oleh lembaga pendidikan (sekolah) bagi murid. Berdasarkan program pendidikan tersebut murid melakukan berbagai kegiatan belajar sehingga mendorong perkembangan dan pertumbuhannya sesuai dengan tujuan pendidikan yang telah ditetapkan. Kurikulum tdak terbatas pada sejumlah mata pelajaran, namun meliputi segala sesuatu yang dapat mempengaruhi

${ }^{17}$ Samsul Nizar, Sejarah Pendidikan Islam: Menelusuri Jejak Sejarah Pendidikan Era Rasulullah Smapai ke Indonesia, (Jakarta: Prenadamedia Group, 2016), hal. 231 
perkembangan murid, seperti: bangunan sekolah, alat pelajaran, perlengkapan sekolah, perpustakaan, karyawan, tata usaha, gambargambar, halaman sekolah ${ }^{18}$. Dari hasil olah informasi penulis, dapat satu fakta yang sekiranya merupakan bentuk implementasi manajemen kurikulum dalam manajemen pendidikan islam dalam kancah global. Bahwa untuk ketiga negara yang kita bahas di atas, paradigma kurikulum di sana adalah seperti yang diungkapkan James A. Bean dalam karyanya yang berjudul: "Curriculum Planing and Development" yang menyimpulkan adanya empat (4) kategori kurikulum, yaitu:

\section{a. Kurikulum sebagai produk (Curriculum as product)}

Dipahami sebagai dokumen yang berisi tentang daftar mata pelajaran, silabus, daftar keterampilan dan tujuan, judul-judul buku ajar dan sebagainya. Dalam pengertian ini, kurikulum merupakan hasil dari kegiatan perencanaan kurikulum dan pengembangannya.

b. Kurikulum sebagai program ( Curriculum as Prorgram)

Dipahami sebagai program pendidikan yang disediakan oleh sekolah untuk memfasilitasi kegiatan pembelajaran peserta didik. Program pendidikan tersebut dapat berwujud kegiatan-kegiatan intrakurikuler (program terstruktur), kegiatan-kegiatan ko-kurikuler (program sebagai pendalaman terhadap kegiatan intra-kurikuler) dan kegiatan ekstra-kurikuler (program yang bertujuan untuk memberikan wawasan dan keterampilan yang lebih luas bagi peserta didik.

c. Kurikulum sebagai materi pembelajaran yang diperlukan (curriculum as intended learnings)

Dipahami sebagai perencanaan pembelajaran yang memuat sejumlah materi, keterampilan, sikap dan perilaku yang harus dipelajari oleh peserta didik di sekolah. Dalam pengertian ini, kurikulum harus memuat fakta, prinsip, konsep dan pemahamanpemahaman yang berkaitan dengan mata pelajaran yang harus dipelajari oleh para peserta didik di sekolah.

${ }^{18}$ Oemar Hamalik, Manajemen Pengembangan Kurikulum, (Bandung: PT. Remaja Rosdakarya, 2007), hal. 10. 


\section{d. Kurikulum sebagai pengalaman peserta didik (curriculum as the experineces of the learners)}

Dipahami sebagai serangkain pengalaman belajar peserta didik yang diperoleh melalui proses pembelajaran. Dapat dkatakan bahwa kurikulum pendidikan bukanlah sesuatu yang bersifat fisik tetapi interaksi antara pendidik, peserta didik dan pengetahuan baik di dalam maupun di luar kelas ${ }^{19}$.

Sejauh ini, di Indonesia makna kurikulum itu hanya sebatas kepada poin 1 dari keempat poin di atas. Kurikulum hanya sebatas dokumen yang berisi tentang daftar mata pelajaran, silabus, daftar keterampilan dan tujuan, judul-judul buku ajar dan sebagainya. Namun ketika kita lihat dan bandingkan dengan manajemen kurikulum Finlandia, Singapura dan Jepang, kurikulum dianggap produk, program, materi pembelajaran dan pengalaman peserta didik yang hanya akan ditukar minimal 10 tahun. Untuk Finlandia, kurikulumnya baru ditukar setelah 50 tahun dipakai. Begitu konsistennya para pemimpin negeri Filandia, Singapura dan Jepang dalam mengimplementasikan kebijakan kurikulum yang sudah ditetapkan. Meskipun pemerintahannya silih berganti, namun kebijakan kurikulum tetap mengikuti yang sudah ditetapkan.

Hal itu disebabkan bahwa untuk dapat merubah suatu kebijakan kurikulum, butuh waktu minimal 50 tahun pemakaian kurikulum di suatu negara. Malaysia adalah contoh lainnya. Malaysia membuat perencanaan jangka panjang yang sistematis dan dijalankan secara konsekuen. Jika kita lihat makna kurikulum sebagai materi pembelajaran, maka ada hal uni dari Finlandia, Singapura, jepang dan Malaysia yaitu Kurikulum yang ditetapkan mencakup semua mata pelajaran termasuk pendidikan moral. Pendidikan moral menjadi fokus penting dalam rangka membentuk masyarakat yang bebudaya tinggi dalam hal etika, disiplin dan perilaku sosial sehari-hari. Bagaimana dengan Indonesia? Ganti presiden, maka ganti menteri,

${ }^{19}$ Abdullah Aly, Pendidikan Islam Multikultural di Pesantren, Yogyakarta: Pustaka Pelajar, 2011), hal. 39-42. 
ganti menteri berimbas pula pada pergantian kebijakan. Termasuk kebijakan kurikulum.

Masih segar dalam ingatan kita bahwa belum 4 tahun dicobakan kurikulum berbasis isi dan institusional di Perguruan Tinggi, sekarang sudah diganti lagi dengan kurikuum KKNI. Walaupun sebenarnya sahsah saja pergantian kurikulum terutama karena landasan IPTEKS, namun alangkah lebih bagusnya jika proses pergantian kebijakan kurikulum ini didasari atas hasil evaluasi yang merupakan salah satu dari tiga prosedur manajemen kurikulum yang akan dijelaskan di bawah ini:

\section{1) Perencanaan Kurikulum}

(a) Perencanaan Strategis (Strategic Planing)

Dipahami sebagai kegiatan yang dilakukan dalam rangka perumusan standar kompetensi, penetapan isi dan struktur program, serta penyusunan strategi pelaksanaan kurikulum secara keseluruhan. Ini adalah tanggung jawab dewan dan pihak yang otoritatif di suatu lembaga pendidikan ${ }^{20}$.

(b) Perencanaan Program (Program Planning)

Dipahami sebagai kegiatan yang dilakukan dalam rangka menyusun kompetensi dasar dan menetapkan materi atau pokok bahasan pada setiap mata pelajaran. Pihak yang terlibat adalah bidang kurikulum, kepala sekolah, beberapa guru yang dpilih terutama dipilih berdasakan keahlian disiplin ilmu dan kinerja mereka.

(c) Perencanaan Kegiatan Pembelajaran (Program Delivery plans)

Dipahami sebagai kegiatan yang dilakukan dalam rangka implementasi pembelajaran yang terdiri atas: menyusun indikator pencapaian kompetensi, menentukan materi, menentukan strategi pembelajaran, dan menetapkan alat evaluasi pembelajaran yang akan digunakan. Pihak yang bertugas disini adalah para guru.

${ }^{20}$ Curtis R. fINCH dan John R. Cruncilton, Curriculum Development in Vocational and Technical Education, (London: Allyn and Bacon, 1993), hal. 46 
Jika disajikan dalam bentuk tabel, maka dapat dilihat pada tabel 1 di bawah ini:

Tabel 1. Perencanaan Kurikulum

\begin{tabular}{|l|l|l|}
\hline \multicolumn{1}{|c|}{ Jenis } & \multicolumn{1}{|c|}{ Penanggung Jawab } & \multicolumn{1}{c|}{ Hasil } \\
\hline Rencana Strategis & $\begin{array}{l}\text { Dewan dan pihak } \\
\text { yang otoritatif } \\
\text { (dengan meminta } \\
\text { input dari berbagai } \\
\text { kelompok yang ada } \\
\text { dalam suatu } \\
\text { lembaga). }\end{array}$ & $\begin{array}{l}\text { Standar kompetensi, } \\
\text { isi dan struktur } \\
\text { program, strategi } \\
\text { pelaksanaan } \\
\text { kurikulum secara } \\
\text { keseluruhan }\end{array}$ \\
\hline Rencana Program & $\begin{array}{l}\text { Staff ditingkat pusat } \\
\text { dan kepala sekolah } \\
\text { (dengan meminta } \\
\text { masukan dari guru } \\
\text { dan staf sekolah) }\end{array}$ & $\begin{array}{l}\text { Kompetensi dasar dan } \\
\text { materi atau pokok } \\
\text { bahasan pada setiap } \\
\text { mata pelajaran }\end{array}$ \\
\hline $\begin{array}{l}\text { Rencana program } \\
\text { pembelajaran }\end{array}$ & $\begin{array}{l}\text { Guru, konselor, dan } \\
\text { staff (dengan } \\
\text { meminta masukan } \\
\text { dari orang tua, } \\
\text { peserta didik, dan } \\
\text { anggota masyarakat) }\end{array}$ & $\begin{array}{l}\text { Indikator pencapain } \\
\text { kompetensi, materi } \\
\text { pembeljaran, strategi } \\
\text { pembeljaran dan } \\
\text { evaluasi } \\
\text { pembelajaran }\end{array}$ \\
\hline
\end{tabular}

Sumber: (Curtis R. Finch dan John R. Crunkilton dalam Abdullah Aly, 2011:71)

2) Implementasi Kurikulum

Terdapat emapt (4) model implementasi kurikulum yang dapat dipilih, yaitu:

(a) Program pendidikan berbasis individu

Dipahami sebagai program pendidikan yang menempatkan peserta didik sebagai komponen utama, sementara hal lain diluar peserta didik hanya merupakan komponen yang bersifat komplementer.

(b) Pembelajaran berbasis modul

Dipahami sebagai kegiatan pembelajaran yang menempatkan modul sebagai komponen utama. Didasari atas asumsi bahwa peserta 
didik akan lebih berprestasi jika dipandu oleh tujuan pembelajaran dan materi yang tersusun dalam suatu modul.

(c) Pendidikan berbasis kompetensi

Dipahami sebagai program pendidikan yang lebih menekankan kepada kompetensi peserta didik baik yang berupa pengetahuan, tugas, keterampilan, sikap, nilai maupun penghargaan untuk mencapai keberhasilan dalam hidupnya.

(d) Kewirausahaan berbasis sekolah

Dipahami sebagai program pendidikan yang membawa kegiatan kewirausahaan ke dalam sekolah, yang melibatkan peserta didik ${ }^{21}$.

3) Evaluasi Kurikulum

Terdapat dua (2) model dalam evaluasi kurikulum, yaitu:

1) Model Saylor, Alexander dan Lewis

Model ini menekankan evaluasi kurikulum kepada lima aspek, yaitu: (1) tujuan kurikulum/ tujuan institusional, kurikuler dan tujuan pembelajaran, (2) program pendidikan secara keseluruhan, (3) segmen tertentu program pendidikan, (4) pembelajaran dan (5) evaluasi program.

\section{2) Model CIPP Stuffiebeam}

Model ini menekankan evaluasi pada empat aspek, yaitu (1) konteks, (2) input, (3) proses dan (4) produk.

\section{Manajemen Sarana dan Prasarana Pendidikan Islam}

Salah satu sarana dalam lembaga pendidikan terkait implementasi manajemen pendidikan islam yang saat ini masih eksis dan dilakukan secara continue oleh negara Singapura sebagai negara terbaik dalam kualitas pendidikannya adalah menjadikan masjid sebagai lembaga tempat belajar. Di Singapura saat ini terdapat 70 masjid. Masjid di Singapura terkenal dengan kebersihannya dan keindahannya. Pada ruas kanan dan kiri di setiap masjid terdapat ruangan-ruangan kelas untuk belajar agama dan kursus keterampilan. Berbagai disiplin ilmu agama diajarkan setiap siang dan sore hari ${ }^{22}$.

\footnotetext{
${ }^{21}$ Ibid, hal. 261

22 (http://www.muslimsource.com).
} 
Aktivitas lainnya, diskusi berbagai masalah kontemporer dan keislaman. Diskusi ini biasanya diadakan oleh organisasi remaja di setiap masjid. Dewan pengurus setiap masjid juga menerbitkan media (majalah dan buletin) sebagai media dakwah dan ukhuwah sesama muslim. Berbeda dengan di negara lainnya, para pengurus masjid digaji khusus, dan memiliki ruangan pengurus eksekutif layaknya perkantoran modern. Selain pendidikan agama Islam, siswa juga belajar tentang subjek umum. Para siswa mempelajari agama Islam sementara mereka juga mempelajari subjek-subjek non Islam. Madrasah Al Irsyad Al Islamiah di Singapura menjadi contoh pendidikan Islam yang sejalan dengan dunia modern di negeri singa tersebut ${ }^{23}$.

Praktik pendidikan islam yang masih terus dilakukan sampai saat ini adalah bukti bahwa muslim di Singapura sangat menjaga dan melestarikan sejarah awal pendirian lembaga pendidikan islam di zaman Rasulullah. Rasulullah dalam mengajarkan Islam kepada para sahabat zaman periode mekkah, menggunakan rumah sebagai lembaga pendidikan pertama. Rumah itu bernama Al-Arqam ibn Abi al-Arqam $^{24}$. Karena jumlah sahabat Nabi yang belajar Islam terus bertambah, maka nabi menjadikan masjid sebagai lembaga pendidikan untuk belajar Islam. Itulah yang dilestarikan oleh Singapura sebagai negara dengan jumlah penduduk muslim yang tidak mayoriyas seperti Indonesia. Lalu, bagaimana dengan Negeri kita tercinta Indonesia? Sudahkan seperti Singapura dalam menjaga tradisi Islam?

\section{KESIMPULAN}

Berdasarkan pemaparan Bab 1 Pendahuluan dan Bab II Pembahasan, dapat disimpulkan bahwa:

1. Manajemen pendidikan Islam adalah suatu proses pengelolaan secara islami terhadap lembaga pendidikan islam dengan cara menyiasati sunber-sumber belajar dan hal-hal yang terkait untuk mencapai tujuan pendidikan islam secara efektif dan efisien

\footnotetext{
${ }^{23}$ Ibid

${ }^{24}$ Ramayulis, Ilmu Pendidikan Islam, (Jakarta: Kalam Mulia, 2004), hal. 215.
} 
2. Implementasi manajemen pendidikan islam dalam lingkup local adalah:

a. Faktor ideology negara yang terdiri orde lama, orde baru dan orde reformasi

b. Factor perkembangan masyarakat

c. Factor perkembangan ilmu pengetahuan

3. Implementasi manajemen pendidikan islam dalam lingkup global dapat dilihat dari manajemen komponen-komponen dasar pendidikan islam, yaitu:

a. Manajemen personalia pendidikan islam

b. Manajemen kesiswaan pendidikan islam

c. Manajemen kurikulum pendidikan islam

d. Manajemen sarana dan prasarana pendidikan islam

\section{Daftar Pustaka}

Abdullah Aly. Pendidikan Islam Multikultural di Pesantren. (Yogyakarta: Pustaka Pelajar, 2011).

Abuddin Nata. Paradigma Pendidikan Islam: Kapita Selekta Pendidikan Islam. (Jakarta: Gramedia Widiasarana, 2011).

Altaf Gauhar. Tantangan dalam Pendidikan Islam. (Jakarta: Raja Grafindo Persada, 2006).

Amrullah Ahmad, et.al. Dimensi Hukum Islam dalam Sistim Hukum Nasional (Cet. I; Jakarta: Gema Insani Press, 1996), h. xi. Lihat juga Amir Mu'allim dan Yusdani, Konfigurasi Pemikiran Hukum Islam (Cet. I; Yogyakarta: UI Press, 1999).

Curtis R. fINCH dan John R. Cruncilton. Curriculum Development in Vocational and Technical Education. (London: Allyn and Bacon, 1993).

Deliar Noer. Pembangunan di Indonesia. (Jakarta: Mutiara, 2004).

Imam Gunawan dan Djum Djum Noor Benty. Manajemen Pendidikan: Suatu Pengantar Praktik. (Bandung: Alfabeta CV, 2017). 
Mujami Qomar. Manajemen Pendidikan Islam: Strategi Baru Pengelolaan Pendidikan Islam. (Jakarta : Erlangga, 2007).

Mujamil Qomar. Manajemen Pendidikan Islam. (Jakarta: Erlangga, 2015).

Mujammil Qomar. Manajemen Pendidikan Islam. (Jakarta: Erlangga, 2007).

Muwahid Shulhan. Manajemen Pendidikan Islam, (Yogyakarta:Teras,2013).

Nanang Fattah. Landasan Manajemen Pendidikan. (Bandung: Rosdakarya, 2002).

Oemar Hamalik. Manajemen Pengembangan Kurikulum. (Bandung: PT. Remaja Rosdakarya, 2007).

Ramayulis. Ilmu Pendidikan Islam. (Jakarta: Kalam Mulia, 2004).

Robbin dan Coulter. Manajemen (edisi kedelapan). (Jakarta, PT Indeks 2007).

Samsul Nizar. Sejarah Pendidikan Islam: Menelusuri Jejak Sejarah Pendidikan Era Rasulullah Smapai ke Indonesia. (Jakarta: Prenadamedia Group, 2016).

Sulistyorini, M. Faturrohman. Esensi Manajemen Pendidikan Islam. (Yogyakarta:Teras, 2014).

Sulistyorini. Manajemen Pendidikan Islam. (Yogyakarya: Teras, 2009). (http://www.muslimsource.com). 